\title{
Ketentuan dan Akibat Hukum terhadap Penghapusan dan Pemusnahan Barang Milik Negara (ASET) Berdasarkan Peraturan Menteri Keuangan
}

\author{
Masriyani $^{1 *}$, Vira Sekar Ningrum ${ }^{2}$ \\ ${ }^{1,2}$ Fakultas Hukum, Universitas Batanghari Jambi, Indonesia \\ *Correspondence email: masriyani@unbari.ac.id; vyra.sekar17@gmail.com
}

\begin{abstract}
Abstrak. Isu sentral dalam sistem pengelolaan Barang Milik Negara (aset) adalah pelaksanaan pengelolaan Barang Milik Negara (aset) didasarkan pada asas fungsional, kepastian hukum, transparansi, efisiensi, akuntabilitas, dan kepastian nilai. Keputusan Menteri Keuangan Nomor 470/KMK.01/1994 tentang Tata Cara Penghapusan dan Pemanfaatan Barang Milik. Kekayaan Negara, Keputusan Menteri Keuangan Nomor 350/KMK.03/1994 tentang Tata Cara Tukar Menukar Barang Milik/Kekayaan Negara. Dari sisi peraturan, ketentuan-ketentuan tersebut masih banyak kelemahannya terutama di bidang sistem perundang-undangan masih bersifat partial, dimana peraturan tersebut belum terpadu dan menyeluruh, masing-masing dari setiap peraturan tersebut masih tumpang tindih dan berdiri sendiri sehingga tidak merupakan suatu kesatuan dan tidak ada kaitannya antara peraturan yang dibawah dengan yang atasnya dalam suatu pokok permasalahan kebijakan pengelola Barang Milik Negara (BMN). Penulisan ini bertujuan untuk memahami dan mengalisa bagaimana akibat hukum yang ditimbulkan dari system perundanga-ungdangan yang mengatur tentang penghapusan barang milik Negara tersebut dengan menggunakan metode pendekatan adalah pendekatan perundang-undangan. Sehingga pada hasil dari penulisan dapat memberikan gambaran dan analisis terhadap permasalahan penghapusan dan pemusnahan barang milik Negara sebagaimana belum diatur di peraturan perundang-undangan yang khusus.
\end{abstract}

Kata Kunci: barang milik negara; penghapusan dan pemusnahan

\begin{abstract}
The central issue in the management system of State-Owned Goods (assets) is the implementation of the management of State-Owned Goods (assets) based on functional principles, legal certainty, transparency, efficiency, accountability, and certainty of value. Decree of the Minister of Finance No. 470/KMK.01/1994 on Procedures for the Elimination and Utilization of Property. State Wealth, Decree of the Minister of Finance No. 350/KMK.03/1994 on The Procedure for Exchanging Property/State Wealth. In terms of regulations, the provisions are still many weaknesses, especially in the field of the legal system is still partial, where the regulations are not yet integrated and thorough, each of these regulations still overlaps and stands alone so that it is not a union and has nothing to do between the regulations below and the above in a matter of the policy of the management of State Owned Goods (BMN). This writing aims to understand and understand how the legal consequences generated from the legal system governing the removal of state property by using the approach method is a statutory approach. So that the results of the writing can provide an overview and analysis of the issue of the removal and destruction of state-owned goods as not yet regulated in the special legislation.
\end{abstract}

Keywords: state-owned goods; removal and destruction

\section{PENDAHULUAN}

Pernyataan yang tertulis dalam dalam dasar hukum di Negara Indonesia, Undang-Undang Dasar Republik Indonesia Tahun 1945, sebagaimana dalam Pasal 33 ayat 2 yang menyebutkan kekayaan alam yang ada dalam Negara Indonesia termasuk bumi dan air yang terkandung didalamnya hak penguasaannya ada di negara dan diperuntukan sebesar-besar pada kemakmuran rakya, maka dari uraian tersebut diatas dapat diartikan bahwa negara punya kekuasaan dalam bidang pengelolaan seluruh sumber daya alam yang ada.

Sebelum reformasi keuangan negara, kebijakan pengelolaan barang milik negara diatur dalam Indonesische Comtabiliteits Wet (ICW)/ Undang-Undang yang berisi tentang landasan peraturan dalam membuat undang-undang pada masa Hindia-Belanda, yang mencakup tentang pembendaharaan negara Tahun 1925 Nomor 448, Keputusan Presiden Nomor 42 Tahun 2002 tentang Pedoman Pelaksanaan APBN juga menjadi suatu pedoman dalam aset negara, di dalam Keputusan Menteri Keuangan Nomor 470/KMK.01/1994 tentang Tata Cara Penghapusan dan Pemanfaatan Barang Milik. Kekayaan Negara, Keputusan Menteri Keuangan Nomor 350/KMK.03/1994 tentang Tata Cara Tukar Menukar Barang Milik/Kekayaan Negara. Dari sisi peraturan, ketentuan-ketentuan tersebut masih banyak kelemahannya terutama di bidang sistem perundang-undangan masih bersifat partial belum terpadu dan menyeluruh, dimana masing-masing peraturan tersebut berdiri sendiri dan merupakan yang tidak suatu kesatuan sehingga antara peraturan diatas dan dibawah tidak saling berkaitan dalam suatu pokok permasalahan kebijakan pengelola Barang Milik Negara (BMN) yang selanjutnya akan disebut aset negara.

Regulasi dari kebijakan pengelolaan aset negara sebelum reformasi bidang keuangan negara memberikan dampak keadaan/kondisi riil dalam pengelolaan Barang Milik Negara (BMN) antara lain sebagai berikut:

1. Adanya dikotomi antara pengelolaan uang dengan pengelolaan barang;

2. Kurangnya concern dalam pengelolaan barang dibandingkan pengelolaan uang; 
3. Point of view pengelolaan barang umumnya masih terbatas pada pengadaan, pemanfaatan dan penghapusan;

4. Pengelolaan aset cenderung cost oriented daripada benefit oriented;

5. Prosedur pembukuan aset belum memenuhi kaidah standar akuntabilitas public;

6. Pencatatan nilai dalam Laporan Keuangan (Neraca) belum mencerminkan nilai wajar dan/atau tidak sesuai kondisi riil;

7. Belum memadainya peraturan tentang pengelolaan barang untuk memenuhi perkembangan kebutuhan dalam praktek;

8. Kurangnya pengetahuan dan kemampuan SDM pengelola barang;

9. Kurangnya dukungan sistem informasi dalam pengelolaan aset. ${ }^{1}$

Kondisi ini menimbulkan beberapa permasalahan dalam pengelolaan Barang Milik Negara (aset) yaitu:

1. Sebuah pengelolaan aset, yang paling utama penggunaan, lalu pemanfaatan, pemindahtanganan dan yang terakhir penghapusan dan pemusnahan yang tidak relevan dengan aturan yang berlaku:

a. Belum/tidak memenuhi syarat dan atau sebuah prosedur yang telah ditetapkan.

b. Tidak memiliki bukti persetujuan atau izin pejabat yang berwenang.

c. Proses pengelolaan yang tidak mengikuti proses tender/lelang.

d. Harga atau tarif tidak wajar.

e. Hasil dalam penerimaan tidak disetor ke rekening kas negara.

2. Adanya aset-aset yang berlebih jumlah dan/atau belum dimanfaatkan secara optimal dan dengan baik.

3. Ketidakjelasan nya status kepemilikan dan/atau status penggunaan aset

4. Tumpang tindihnya kepemilikan yang berujung padas sengketa kepemilikan, pengelolaan, kewenangan penguasaan, hak penggunaan, dan pemanfaatan aset antara institusi pemerintah baik antara pemerintah pusat dengan pemerintah daerah atau antara pemerintah pusat/daerah dengan pihak lainnya.

5. Gugatan dari pihak lain atas kepemilikan dan/atau penguasaan aset oleh pemerintah pusat dan/atau daerah

6. Okupasi/penguasaan aset negara oleh pihak lain

7. Berkurangnya/hilangnya aset milik negara

8. Disatu pihak banyak kementerian lembaga yang mempunyai/menguasai tanah dan/atau bangunan yang berlebihan, sedangkan di lain pihak masih ada Kementrian/Lembaga yang membutuhkan tanah dan/atau bangunan. ${ }^{2}$

Isu sentral dalam sistem pengelolaan Barang Milik Negara (aset) adalah pelaksanaan pengelolaan Barang Milik Negara (aset) didasarkan pada asas fungsional, kepastian hukum, transparansi, efisiensi, akuntabilitas, dan kepastian nilai. Dalam Peraturan Pemerintah Nomor 27 Tahun 2014 disebutkan bahwa pengelolaan Barang Milik Negara (aset) meliputi:

1. Perencanaan kebutuhan, penganggaran dan pengadaan

2. Penggunaan Barang Milik Negara

3. Pemanfaatan dan Pemindahtanganan

4. Pengamanan dan Pemeliharaan

5. Penilaian

6. Pemusnahan

7. Penghapusan

8. Penatausahaan

9. Pembinaan, Pengawasan dan Pengendalian

Dari uraian yang telah dipaparkan dan dijelaskan diatas, maka penulisan karya ilmiah ini lebih mefokuskan masalah pada penghapusan dan pemusnahan barang milik negara. Yang mana kontrol terhadap eksistensi aset negara dapat dilakukan dengan melaksanakan sebuah administrasi berupa pembukuan dalan pencatatan pada daftar barang dan kemudian dapat pula di laporkan dalam bentuk laporan keuangan dari pemerintah. Seringkali kita menemukan Aset negara sebagai bagian dari Aset di neraca laporan keuangan pemerintahan. Dalam praktik, terbitnya keputusan penghapusan Barang Milik Negara terjadi melalui prosedur yang seringkali menjadi sesuatu yang dikatakan sangat sulit dan rumit dan membutuhkan waktu yang relative sangan lama. Sesuatu yang dianggap rumit atau sulit karena banyak persyaratan yang harus dipenuhi untuk mendapat persetujuan penghapusan dan pemusnahan. Proses otorisasi dan kewenangan dari tindakan penghapusan dan pemusnahan aset negara juga tidak cukup dari pejabat di level

\footnotetext{
${ }^{1}$ http://Digilid.Unila.ac.id, Penetapan Status Penggunaan Barang Milik Negara Dalam Rangka Optimalisasi Barang Milik Negara, hal. 3, Diakses Pada Tanggal 17 Mei 2020.

${ }^{2}$ http://Digilid.Unila.ac.id, Penetapan Status Penggunaan Barang Milik Negara Dalam Rangka Optimalisasi Barang Milik Negara hlm 4-5.
} 
operasional saja. Kerumitan persyaratan dan proses otorisasi tersebut selanjutnya berdampak pada lamanya waktu penyelesaian penghapusan Barang Milik Negara.

Proses penghapusan Barang Milik Negara ini tidak sederhana bagi institusi pemerintah. Karena konsekuensi tindakan penghapusan dan pemusnahan tersebut merupakan sebuah kebebasan dari pengelola barang, pengguna barang, dan/atau kuasa pengguna barang dari sebuah tanggung jawab administrasi dan fisik atas suatu barang yang berada dalam penguasaannya di dalam (pasal 1 poin 23 PP 27/2014). Melihat dampak yang begitu penting dari penghapusan dan pemusnahan tersebut aka seyogyanya tindakan tersebut harus didasari oleh sebuah keputusan resmi dari pejabat yang memilki kewenangan untuk tindakan tersebut.

Dalam PP Nomor 27 Tahun 2014, diartikan penghapusan tersebut, sebagai suatu tindakan yang menghapus aset negara (barang milik negara) dari daftar barang dengan melakukan penerbitan sebuah keputusan pejabat yang memiliki kewenangan untuk membebaskan pengelola aset, pengguna barang, dan/atau kuasa pengguna barang dari tanggung jawab administrasi dan fisik atas barang yang berada dalam penguasaannya. Regulasi ini merupakan salah satu lingkup dari pengelolaan aset negara/daerah yang diatur dalam Peraturan pemerintah tersebut.

Selanjutnya untuk tindakan penghapusan dan pemusnahan ini oleh ditetapkanlah lebih lanjut lagi oleh Kementerian Keuangan Negara di dalam Peraturan Menteri Keuangan (PMK). Akan tetapi peraturan ini tentunya menimbulkan akibat hukum baik secara administrasi maupun secara fisik baik terhadap kewenangan pengelolaan maupun terhadap fisik dari aset Negara itu sendiri.

\section{METODE}

Penelitian dan penulisan karya ilmiah ini merupakan penelitian dengan tipe penelitian hukum normatif yang dilakukan dengan menggunakan metode pendekatan perundang-undangan (statute approach), yang melakukan penelitian terhadap norma hukum yang berkaitan dengan pengelolaan kekayaan negara umumnya dan mengenai penghapusan dan pemusnahan khususnya. Selain itu juga dilakukan metode pendekatan historis (historical approach), dengan mengkaji perkembangan norma hukum yang berkaitan dengan pengelolaan kekayaan negara dan kententuan penghapusan dan pemusnahan khususnya.

Dalam penelitian ini, penulis melakukan kegiatan berupa penelitian dengan tehnik penelitian pustaka (library research) yang selanjutnya hasil penelitian tersebut di dokumentasikan dengan cara menilai bahan bahan hukum yang berhubungan dengan masalah yang diteliti dan mengevaluasi peraturan perundanga-undangan yang berhubungan dengan masalah yang diteliti, yang di kelompokan sebagai data primer penelitian ini. Sebagai data pendukung dilakukan pula penelitian lapangan di lokasi yang dilakukan tindakan pemusnahan aset, yaitu pulau berhala yang dijadikan sebagai data pendukung (sekunder).

Selanjutnya agar penelitian ini tidak meluas ke segala permasalahan maka penulis membatasi ruang lingkup penelitian terhadap ketentuan yang mengatur penghapusan dan pemusnahan barang milik negara saja, dan mengalisa akibat hukum yang ditimbulkan dari tindakan tersebut. Hasil penelitian dituangkan dalam bentuk karya ilmiah yang bersifat deskriptif analitis sehingga dapat memberikan gambaran yang jelas, menyeluruh dan sistematis mengenai permasalahan yang dibahas.

\section{HASIL DAN PEMBAHASAN}

Dalam pelaksanaan penghapusan dan pemusnahan barang milik negara (aset) tentunya dalam praktik terdapat dasar hukum yang mesti ditaati dan dilaksanakan sesuai ketentuan yang berlaku dalam Undang-undang. Yang mana penjelasan tersebut dapat dilihat dari berbagai peraturan-peraturan terkait.

Undang-undang Nomor 17 Tahun 2003 tentang Keuangan negara lebih mengatur pada bagaimana melakukan pengelolaan kekayaan negara. Peraturan lain yang terkait dalam undang-undang keuangan negara ini adalah Undangundang tentang Pembendaharaan Negara yaitu Undang-undang nomor 1 Tahun 2004, selanjutnya juga diatur tentang pemeriksaan pengelolaan dan tanggung jawab keuangan negara yaitu Undang-undang Nomor 15 Tahun 2004.

Khusus kepada masalah kekayaan negara sampai saat ini belum diatur melalui Undang-Undang tersendiri tentang pengelolaan kekayaan negara. Tetapi, telah diterbitkan Peraturan yang mengatur tentang pengelolaan barang milik negara/daerah melalui Peraturan Pemerintah Republik Indonesia Nomor 27 Tahun 2014. Di dalam PP Nomor 27 Tahun 2014 ini diatur tentang penghapusan dan pemusnahan barang milik negara (aset) sebagaimana dijelaskan dalam pasal 77 akan dilakukan pemusnahan jika barang milik negara/daerah tidak dapat dipergunakan lagi, tidak dapat dimanfaatkan lagi, dan atau tidak dapat dipindahtangankan atau ada alasan lain yang sesuai dengan ketentuan peraturan perundang-undangan. Untuk pemusnahan selanjutnya diatur ketentuan lebih lanjut mengenai tata cara pelaksanaannya melalui peraturan menteri keuangan.

Sedangkan pengaturan tentang penghapusan diatur dalam pasal 81 Peraturan Pemerintah Nomor 27 Tahun 2014 sebagaimana dijelaskan bahwa penghapusan meliputi dari dua kategori yakni penghapusan yang dilakukan dengan menghapus dari daftar barang pengguna dan atau daftar barang kuasa pengguna dan penghapusan dengan 
melakukankan tindakan menghapus aset tersebut dari daftar barang milik negara/daerah. Untuk penghapusan juga diatur lebih lanjut melalui Peraturan Menteri Keuangan.

Secara teknis pelaksanaan penghapusan dan pemusnahan barang milik negara diatur melalui Peraturan Menteri

Keuangan Republik Indonesia Nomor 83/PMK.06/2016. Peraturan Menteri Keuangan ini lebih mengatur kepada tata cara pelaksanaan pemusnahan dan penghapusan barang milik negara. Didalam peraturan menteri keuangan ini tanggung jawab dari pemusnahan dan penghapusan barang milik negara merupakan kewenangan dari Menteri Keuangan Negara. Kewenangan dan tanggung jawab tersebut secara fungsional dilaksanakan oleh pejabat struktural pada unit organisasi yang membidangi pengelolaan barang milik negara. Dalam Peraturan Menteri Keuangan ini juga menjelaskan bahwa pemusnahan dapat dilakukan pada barang milik negara berupa bangunan, Sebagaimana berdasarkan pengamatan penulis terjadi pemusnahan bangunan di wilayah pulau Berhala. Kemudian pemusnahan juga dapat dilakukan dengan cara dihancurkan, dibakar, ditimbun, ditenggelamkan, dirobohkan atau cara lain sesuai ketentuan peraturan perundang-undangan.

Didalam pelaksanaan tata cara pemusnahan barang milik negara yang tercantum pada Peraturan Menteri Keuangan Nomor 83/PMK.06/2016 pun juga terdapat 2 (dua) proses pelaksanaan pemusnahan barang milik negara, antara lain:

1. Dalam Pasal 9, secara tekhnis proses pelaksanaan pemusnahan barang milik negara Peraturan Menteri Keuangan Nomor 83/PMK.06/2016 menjelaskan bahwa penghapusan yang berada pada pejabat pengelola barang terhadap aset Negara/barang, maksudnya sipengelola barang melakukan penelusuran dan penelitian terhadap aset negara yang akan dilakukan pemusnahan yang meliputi penelitian administratif seperti penelitian data dan dokumen barang milik negara juga penelitian secara fisik guna mencocokkan fisik barang milik negara yang akan dilakukan tindakan pemusnahan dengan data secara administratif. Selanjutnya penelitian tersebut dituangkan dalam laporan yang berisikan hasil dari penelitian dan hasil penelitian tersebut dinyatakan layak atau patut dan memenuhi persyaratan, maka kuasa pengelola barang menetapkan keputusan pemusnahan barang milik negara. Berdasarkan keputusan pemusnahan yang dimaksud pengelola barang selanjutnya melakukan pemusnahan barang milik negara dengan jangka waktu paling lama 1 (satu) bulan sejak tanggal keputusan pemusnahan barang milik negara ditetapkan lalu pelaksanaan pemusnahan pemusnahan di tuangkan dalam berita acara pemusnahan dan berita acara tersebut disusun sistematis sesuai format dan ketentuan yang telah dicantumkan dalam lampiran I dari Peraturan Menteri Keuangan.

2. Dalam bagian ke 5 pasal 10 prosedur dalam pelaksanaan pemusnahan barang milik negara yang berada pada pengguna barang, maka pengguna barang melakukan proses persiapan dengan mengajukan permohonan tindakan pemusnahan yang meliputi penelusuran dan penelitian administratif dan penelitian fisik dari aset negara tersebut.. Dalam rangka pelaksanaan pemusnahan barang milik negara pengguna barang dapat membentuk tim internal dan selanjutnya mengajukan permohonan pemusnahan kepada pengelola barang yang memuat pertimbangan dan alasan pemusnahan. Dalam Peraturan Menteri Keuangan Nomor 83/PMK.06/2016 tentang Pemusnahan dan Penghapusan Barang Milik Negara Pasal 11 juga menyebutkan bahwa dalam pemusnahan pengguna barang mengajukan permohonan pemusnahan barang milik negara kepada pengelola barang yang sekurang-kurangnya memuat pertimbangan dan alasan pemusnahan barang milik negara dan data barang milik negara yang akan dimusnahkan, sekurang-kurangnya memuat tahun perolehan, identitas barang, dan nilai perolehan dan/atau nilai buku. Yang kedua permohonan pemusnahan barang milik negara sebagaimana dimaksud pada ayat (1) Peraturan Menteri Keuangan Nomor 83/PMK.06/2016 menyebutkan bahwa harus disertai dokumen seperti sebagai berikut:

a. Dalam Peraturan Menteri Keuangan Nomor 83/PMK.06/2016 menjelaskan bahwa Surat pernyataan dari pengguna barang/kuasa barang yang sekurang-kurangnya memuat identitas pengguna barang/kuasa pengguna barang, selain itu pengguna barang/aset membuat pernyataan mengenai tanggung jawabnya yang penuh atas kebenaran dan keabsahan atas permohinan yang diajukan, baik secara materiil maupun secara formil. Dan surat pernyataan yang menyatakan bahwa barang/aset Negara benar benar tidak dapat dipergunakan lagi, atau dimanfaatkan, dan/atau dipindahtangankan atau barang/aset negara tersebut harus dilakukan pemusnahan dengan merujuk dan berdasarkan ketentuan peraturan perundang-undangan.

b. Berbagai dokumen kepemilikan yang difotokopi untuk barang/aset negara yang harus disertai dan dilengkapi dengan dokumen kepemilikan

c. Tanda atau kartu identitas barang, untuk barang/aset negara yang harus disertai dengan tanda berupa kartu identitas barang/aset negara tersebut

d. Hasil berupa laporan mengenai kondisi dari barang/aset Negara.

e. Dokumen berupa foto terbaru atau terkini dari barang/aset negara

Dalam hal dokumen atas kepemilikan sebagaimana dimaksud tersebut huruf $\mathrm{b}$ didalam Permenkeu Nomor 83/PMK.06/2016 tidak ada, maka dapat diganti dengan dokumen lainnya yaitu: 
1. Dokumen lain, seperti dokumen-dokumen kontrak, akta seperti akta jual beli dari aset/barang tersebut, surat perjanjian jual beli, dan dokumen serta lainnya yang dapat dikatakan sama atau dipersamakan dengan dokumen kepemilikan tersebut.

2. Akta atau surat pernyataan yang diberi materai dengan nilai yang cukup ditandatangani oleh pejabat structural yang memiliki kewenangan pada Kementerian/Lembaga bersangkutan yang isisnya menyatakan bahwa aset milik negara yang akan dilakukan pemusnahan tersebut merupakan barang/aset milik negara pada kementerian atau lembaga institusi yang bersangkutan.

Didalam proses permohonan pemusnahan pengelola barang mesti melakukan penelitian terhadap permohonannya tersebut untuk mendapatkan persetujuan akan pemusnahan barang milik negara sebagaimana dimaksud dalam Pasal 11 ayat (1) Peraturan Menteri Keuangan Nomor 83/PMK.06/2016. Penelitian didalam Permenkeu Nomor 83 Tahun 2016 yang dimaksud meliputi penelitian dan penelusuran berbagai data barang/aset negara dan kelengkapan dokumen persyaratan dan juga penelitian fisik, untuk melihat kecocokkan fisik barang/aset negara yang akan dilakukan pemusnahan atau dimusnahkan dengan data dan kondisi secara fisik dari barang/aset Negara yang diperlukan. Dan selanjutnya dengan berdasarkan hasil penelusuran dan penelitian yang dimaksud ialah dalam hal permohonan pemusnahan barang/aset Negara tidak mendapat persetujuan, maka sipengelola barang/aset memberi pemberitahuan kepada sipengguna barang/aset negara yang melakukan pengajuan permohonan disertai dengan alasannya dan apabila permohonan atas pemusnahan barang/aset negara disetujui, maka sipengelola barang/aset negara membuat surat dengan menerbitkan surat persetujuan tindakan pemusnahan barang/aset milik negara.

Berdasarkan Permenkeu Nomor 83/PMK.06/2016 menyebutkan bahwa surat persetujuan pemusnahan terhadap aset/barang milik negara setelah dilakukannya pengajuan secara resmi maka permohonan tersebut paling tidak sekurang-kurangnya memuat dasar pertimbangan dan alasan kenapa disetujuinya tindakan pemusnahan tersebut, data barang/aset negara yang telah disetujui untuk dilakukan tindakan pemusnahan sekurang-kurangnya berisikan tahun diperolehnya tanda/identitas barang/aset dan nilai perolehan dan/atau nilai buku, kewajiban dari sipengguna barang/aset negara untuk melaporkan tindakan dari pelaksanaan pemusnahan barang/aset milik negara kepada pengelola barang. Selanjutnya pengguna barang/aset negara dapat melakukan pemusnahan barang/aset Negara paling lama satu bulan sejak di tetapkannya persetujuan tindakan pemusnahan. Terkecuali untuk barang/aset negara tertentu dalam peraturan perundang-undangan. Kemudian tindakan dari pelaksanaan pemusnahan dituangkan di dalam sebuah berita acara pemusnahan dan ditandatangani oleh pengguna barang/kuasa pengguna barang, yang kemudian berita acara pemusnahan barang milik negara disusun sesuai format yang merupakan bagian dari peraturan menteri keuangan.

Dari uraian diatas penulis menyimpulkan bahwa belum adanya dasar hukum yang kuat yang mengatur khusus pada kekayaan milik negara, oleh karena Undang-undang mengenai pengelolaan kekayaan negara masih dalam tahap Rancangan Undang-undang. Sehingga, Peraturan Pemerintah dan Peraturan Menteri Keuangan masih berpedoman pada Undang-undang Nomor 17 Tahun 2003 Tentang Keuangan Negara. Sedangkan antara keuangan negara dengan kekayaan negara terdapat perbedaan yaitu keuangan negara adalah semua hak dan kewajiban negara yang dapat dinilai dengan uang, serta segala sesuatu baik berupa uang maupun barang yang dapat dijadikan milik negara berhubung dengan pelaksanaan hak dan kewajiban. Sedangkan kekayaan negara adalah semua bentuk kekayaan hayati dan non hayati berupa benda berwujud maupun tidak berwujud, baik bergerak maupun tidak bergerak, yang dikuasai dan/atau dimiliki oleh Negara/Daerah.

Isu sentral dalam sistem pengelolaan Barang Milik Negara (aset) adalah pelaksanaan pengelolaan Barang Milik Negara (aset) didasarkan pada asas fungsional, kepastian hukum, transparansi, efisiensi, akuntabilitas, dan kepastian nilai. Begitupula yang seharusnya berlaku pada tindakan penghapusan dan pemusnahan aset negara. Pada kebanyakan tindakan penghapusan dan pemusnahan aset negara pada umumnya, dilakukan tanpa mempertimbangkan asas pengelolaan barang milik Negara itu sendiri, dimana penghapusan dan pemusnahan yang secara praktik dilakukan lebih berdasarkan pada kepentingan politik, sebagai data pendukung adalah seperti yang terjadi di pulau berhala, dengan dimusnahkannya atau dirobohkannya beberapa bangunan permanen yang sangat layak untuk digunakan di daerah atau wilayah pulau berhala dikarenakan terjadi perpindahan kewenangan pengelolaan aset tersebut dari pemerintah Jambi ke pemerintah kepulauan Riau. Maka keadaan ini, jika kita tinjau dari sisi asas pemanfaatan dalam pengelolaan barang/aset Negara/Daerah , tentunya bangunan tersebut sebenarnya masih dapat digunakan atau dimanfaatkan dengan disewakan untuk kepentingan wisatawan yang datang dan menginap di pulau tersebut atau dapat juga dimanfaatkan sebagai tempat promosi dan penjualan hasil kerajinan setempat atau hasil kekayaan alam di pulau berhala yang tentunya bertujuan untuk peningkatan pendapatan daerah. Ditinjau dari asas fungsional, dalam pengelolaan barang milik Negara yang menitikberatkan pada fungsi dari aset yang selayaknya masih sangat berdaya guna, sehingga aset dapat dimanfaatkan dengan efisien sesuai dengan peruntukannya. Namun satu kasus diatas menunjukan bahwa pemusnahan tersebut bertabrakan dengan asas fungsional dimaksud. 
Penghapusan dan pemusnahan aset tersebut yang hanya mempertimbangan kepentingan tertentu, menjadikan timbulnya kerugian bagi Negara/daerah. Sehingga penting sekali diciptakannya regulasi peraturan atau hukum yang specialis atau khusus terkait pengaturan pemusnahan barang milik Negara/daerah. Karena yang ada saat ini pengaturan pemusnahan masih include dengan pengaturan penghapusan. Barang milik Negara/daerah yang memenuhi kriteria untuk dilakukan penghapusan oleh karena alasan pendataan dan pembukuan karena perpindahan kewenangannya harus ditinjau lagi kemanfaatannya dan kelayakannya sebelum dilakukan penghapusan. Sehingga Negara/daerah tidak mengalami kerugian melainkan menambah pendapatan dan pemasukan bagi negara dan daerah.

Dalam menjalankan penghapusan dan pemusnahan barang milik negara (aset) terdapat proses yang dapat dikatakan cukup rumit. Hal ini dikarenakan banyaknya Peraturan Perundang-undangan yang mengatur tentang keuangan negara, sedangkan aturan pokok mengenai kekayaan negara masih dalam tahap Rancangan Undang-undang tentang Pengelolaan Kekayaan Negara.

Pelaksanaan penghapusan dan pemusnahan barang milik negara (aset) tentunya mengakibatkan pada berbagai macam dampak atau pengaruh terhadap sistem pengelolaan kekayaan negara. Adapun implikasi atau akibat dari pelaksanaan penghapusan dan pemusnahan barang milik negara (aset) adalah menghilangkan fungsi dalam kegunaan dari daftar pengelola dan pengguna barang, selain itu juga berakibat pada terhapusnya tanggung jawab pengelola barang dalam pelaksanaan pengelolaan barang milik negara.

Sedangkan dalam pelaksanaan pemusnahan barang milik negara (aset), dapat menimbulkan akibat hukum yaitu menghilangkan fungsi dan kegunaan barang milik negara secara fisik dan juga menghilangkan tanggung jawab terhadap pengelolaan barang tersebut. Namun, terdapat dampak tersendiri dari pelaksanaan penghapusan dan pemusnahan tersebut seperti ditinjau dari pemanfaatan barang milik negara bahwa barang yang dihapuskan dan dimusnahkan tersebut seharusnya masih dapat digunakan dan dimanfaatkan seperti dapat disewakan, dilelang, dipinjam pakai, diserah gunakan dan lain sebagainya, sehingga ada pemasukan keuangan atau anggaran dari pemanfaatan barang tersebut. Namun, dalam prateknya pelaksanaan penghapusan dan pemusnahan barang milik negara justru menambah penganggaran lebih dalam Keuangan Negara. Sebagai data pendukung seperti kasus yang terjadi di Pulau Berhala dilakukan pemusnahan bangunan yang seharusnya masih bisa dimanfaatkan, hal ini juga mengakibatkan kerugian dalam keuangan dan kekayaan negara.

Bagaimanapun terjadi perkembangan dan perubahan, yang pasti bahwa pemerintah Indonesia telah alpa untuk membentuk peraturan perundang-undangan yang secara khusus mengatur tentang kekayaan negara beserta dengan aturan pengelolaannya. Seperti dijelaskan Jimly Ashiddiqie sebagaimana dikutip dalam Doli D Siregar ${ }^{3}$ memang konstitusi Indonesia, UUD 1945 baik sebelum maupun setelah amandemen, sebagaimana dalam pasal 33, adalah pengaturan dasar kekayaan negara dan ekonomi nasional yang diikhtiarkan sebagai pedoman bagi pengelolaan kekayaan negara dan ekonomi nasional yang lebih khusus lagi. Sama halnya yang terjadi di banyak Negara yang mencantumkan dasar pengelolaan kekayaan negara dan perekonomian nasional ke dalam konstitusinya. Namun yang terjadi dibanyak negara termasuk negara Indonesia dalam prakteknya landasan tersebut dibiarkan menjadi dokumen mati atau formalitas saja (proforma). Secara praktek pengelolaan kekayaan negara dan pengaturan perekonomian nasional hanya berdasarkan pada perkembangan dan tuntutan zaman yakni tuntutan pasar bebas (free market). Dalam kajiannya Jimmly menunjukan banyak undang-undang yang mengatur kekayaan negara dan ekonomi nasional dalam pertimbangannya mencantumkan pasal 33 atau pasal 34 UUD 1945 sebagai konsideran, namun isinya tidak sejalan, bertentangan atau bertolak belakang dengan semangat yang terkandung dalam kedua pasal tersebut. Sebagai contoh adalah undang-undang penanaman modal asing dan undang-undang penanaman modal dalam negeri, memang diatas kertas keduannya merupakan undang-undang investasi, namun dalam prakteknya keduanya berkaitan dengan penguasaan dan pengelolaan kekayaan negara.

Maka dapat dipahami, bahwa hingga saat ini pengaturan mengenai kekayaan negara ini masih tumpang tindih dengan berbagai aturan lain yang terkait, apalagi yang mengatur tentang penghapusan dan pemusnahan barang milk negara. Sampai saat ini pengelolaan kekayaan negara masih berpayung pada undang-undang keuangan negara yang didalamnya juga menjadi dasar dalam sistem perekonomian nasional. Padahal seharusnya negara Indonesia dari sejak awal membentuk undang-undang kekayaan negara dan undang-undang perekonomian nasional. Namun dalam sejarahnya Indonesia justru menerbitkan regulasi tentang investasi yang dapat dilihat dalam UU Penanaman Modal Asing (PMA) yakni UU Nomor 1 Tahun 1967. Sementara undang-undang pengelolaan kekayaan negara masih dalam bentuk rancangan undang-undang sampai saat ini. Akan tetapi dilain puhak negara menerbitkan peraturan pemerintah dan keputusan menteri keuangan yang mengatur pengelolaan kekayaan negara termasuk penghapusan dan pemusnahan aset yang masih berpedoman atau merujuk pada undang-undang keuangan negara. Akibat lanjutannya, tidak ada arah yang jelas dan padu dalam pengeloalaan dan pemanfaatan kekayaan negara. Boleh dibilang selama Negara Indonesia merdeka masih banyak terjadi salah urus terhadap kekayaan negara. 
Dengan demikian regulasi yang terpadu dan runut dalam pengelolaan kekayaan negara yang berlandaskan pada pasal 33 UUD 1945 pada umumnya dan pengaturan penghapusan dan pemusnahan khususnya menjadi sebuah pekerjaan rumah yang sangat penting bagi negara Indonesia. Apalagi melihat perkembangan pasar perekonomian secara global dan perkembangan investasi yang pesat, sudah selayaknya negara memikirkan kekayaan negara yang ada dalam wilayah Indonesia, jangan sampai semua kekayaan atau aset yang ada justru menjadi salah guna, tidak bermanfaat, tidak terdata secara transfaran dan akuntabel, menimbulkan kerugian negara dan menimbulkan konflik kewenangan dalam pengelolaannya.

\section{SIMPULAN}

Di dalam praktik penghapusan dan pemusnahan barang milik negara terdapat dasar hukum yang mengatur lebih lanjut mengenai pengaturan yang membahas mengenai proses terjadinya penghapusan dan pemusnahan barang milik negara. Adapun dasar hukum yang terkait dalam penghapusan dan pemusnahan adalah Undang-undang Nomor 17 Tahun 2003 tentang Keuangan Negara, Undang-undang Nomor 1 Tahun 2004 tentang Pembendaharaan Negara, Undang-undang Nomor 15 Tahun 2004 tentang pemeriksaan pengelolaan dan tanggung jawab keuangan negara yaitu yang isinya tercantum tentang pendapatan, penganggaran keuangan terhadap barang milik negara. Selanjutnya Peraturan Pemerintah Nomor 27 Tahun 2014 tentang Pengelolaan Barang Milik negara yang mana dalam Peraturan tersebut membahas mengenai pengelolaan, perencanaan kebutuhan dan penganggaran, pengadaan, penggunaan, pemanfaatan, pengamanan dan pemeliharaan, penilaian, pemindahtanganan, pemusnahan, penghapusan, penatausahaan, pembinaan, pengawasan dan pengendalian. Setelah itu Peraturan Menteri Keuangan Republik Indonesia Nomor 83/PMK.06/2016 tentang Tata Cara Pelaksanaan Pemusnahan dan Penghapusan Barang Milik Negara. Penghapusan dan pemusnahan aset tersebut yang hanya mempertimbangan kepentingan tertentu, menjadikan timbulnya kerugian bagi Negara/daerah. Sehingga penting sekali diciptakannya regulasi peraturan atau hukum yang baru specialis atau khusus terkait pengaturan pemusnahan barang milik Negara/daerah. Karena yang ada saat ini pengaturan pemusnahan masih include dengan pengaturan penghapusan Barang milik Negara/daerah yang memenuhi kriteria untuk dilakukan penghapusan oleh karena alasan pendataan dan pembukuan karena perpindahan kewenangannya harus ditinjau lagi kemanfaatannya dan kelayakannya sebelum dilakukan penghapusan. Sehingga Negara/daerah tidak mengalami kerugian melainkan menambah pendapatan dan pemasukan bagi negara dan daerah.

Akibat hukum dari tindakan penghapusan dan pemusnahan barang milik negara antara lain terhapusnya fungsi barang milik negara dari daftar barang pengelola dan pengguna barang, hilangnya tanggung jawab pengelola dalam penggunaan, pemanfaatan dan pengelolaan barang milik negara. Penambahan anggaran lebih terhadap keuangan negara akibat terjadinya penghapusan dan pemusnahan barang/aset milik negara. Dalam menjalankan penghapusan dan pemusnahan barang/aset negara terdapat proses yang dapat dikatakan cukup rumit. Hal ini dikarenakan banyaknya peraturan perundang-undangan yang mengatur tentang keuangan negara, sedangkan aturan pokok mengenai kekayaan negara masih dalam tahap Rancangan Undang-Undang tentang Pengelolaan Kekayaan Negara

\section{DAFTAR PUSTAKA \\ Buku}

Bahder Johan Nasution, Metode Penelitian Ilmu Hukum, Mandar Maju, Bandung, 2008.

Doli G Siregar, Kekayaan Negara, Siapa Punya, Siapa Kuasa, SIMA, Jakarta, 2016.

I Made Pesek Diantha, Metodologi Penelitian Hukum Normatif, Prenadamedia Group, Jakarta, 2016

W. Riawan Tjandra, Hukum Keuangan Negara, Grasindo, PT Gramedia Widiasarana Indonesia, Jakarta, 2014.

\section{Peraturan Perundangan}

Undang-Undang Dasar Negara Republik Indonesia 1945

Undang-Undang Nomor 17 Tahun 2003 tentang Keuangan Negara

Undang-Undang Nomor 1 Tahun 2004 tentang Pembendaharaan Negara

Undang-undang Nomor 15 Tahun 2004 tentang Pemeriksaan Pengelolaan dan Tanggung Jawab Keuangan Negara

Peraturan Pemerintah Nomor 27 Tahun 2014 tentang Pengelolaan Barang Milik Negara

Peraturan Menteri Keuangan Nomor 50/PMK.06/2014 tentang Tata Cara Pelaksanaan Penghapusan Barang Milik Negara

Peraturan Menteri Keuangan Nomor 83/PMK.06/2016 tentang Tata Cara Pelaksanaan Pemusnahan dan Penghapusan Barang Milik Negara

\section{Internet}

http://Digilid.Unila.ac.id, Penetapan Status Penggunaan Barang Milik Negara Dalam Rangka Optimalisasi Barang Milik Negara 